\title{
Currant growing technology and mechanized harvesting-review
}

\author{
Olga Panfilova*, Mikhail Tsoy and Olga Golyaeva
}

Russian Research Institute of Fruit Crop Breeding (VNIISPK), Zhilina, Orel district, Orel region, Russian Federation

\begin{abstract}
Currant is a technological, fast-growing, high-yielding crop with a high content of vitamins in the fruit. The intensification of production provides for an increase in the productivity of plantings and a reduction in the cost of production due to the introduction of new cultivation technologies. The main production expenses are connected with harvest. The authors of this paper present the first and modern berry harvesters that reduce the cost of production and ensure high productivity of automated labor. The prospect of using technologies is based on agricultural techniques for cultivating highly productive, disease-and pestresistant currant cultivars with a certain bush habit and physical and mechanical parameters of berries. Scientists have developed new breeding programs for Ribes, taking into account the genetic characteristics of the cultivar. The review presents the main cultivars of currants grown commercially in Europe, the USA, and Russia. Information about crop cultivation technologies is summarized and analyzed.
\end{abstract}

\section{Introduction}

An important stage in the development of modern industry in the field of agriculture is the use of automation and mechanization at all stages of crop production. A properly selected automated and mechanized crop growing system is a crucial factor of competitive

production and reducing the cost of production. Achievements in the field of agriculture,

including the use of tractors, trucks, combines, a computerized GPS monitoring system, etc., open up a number of opportunities and prospects for further industrial development of production for different types of crops.

The gradual replacement of manual labor with automated tools is a definite breakthrough in agriculture. The search for and use of cheap labor, which is usually immigrants and high competition from the world market, were the main reasons that led to the use of new automated tools by farmers in production $[31,52,53]$. At the same time, the use of modern technical equipment requires significant investments (costs) at the first stages [24].

\footnotetext{
*Corresponding author: olga_280682@mail.ru
} 
Currant cultivation is very popular among commercial producers in Eastern and Western Europe (Poland, Germany, Great Britain, Scandinavia, New Zealand, etc.), as well as in

Russia, Ukraine, Canada, and the United States [12]. Currant is a high-yielding and early- fruiting crop, rich in vitamins A, B, C, pectins and phenolic compounds, has a long period of fruiting and at the same time retains an acceptable market quality of berries for a week or more. Thus, white currants can yield up to 9 ton/acre (20 tha-1), red currants from 4.5 to 7 ton/acre (10 to 16 tha-1), black currants from 2 to 4.5 ton/acre (4.5 to 10 tha- 1 ) [9, $27,39,42,53]$. There is a high demand for the production of currant berries in frozen and processed form (puree, juice, marmalade, jam, pastille, etc.) [44].

Currant cultivation on an industrial scale in Europe dates back to the early 20th century (1900s). Currently, the leading countries producing red and black currant berries are Germany, France, Poland, Great Britain, Holland, Belgium, France, Russia, Hungary, and Ukraine [25, http://www.fao.org/faostat/ru/\#data/QC, 2018]. Slovakia and Germany are considered leaders in the production of white currant berries [26]. On a small scale, red currants are grown in the northern part of the United States and southern Canada [8].

\section{Results and Discussion}

\subsection{Mechanized harvesting of the yield}

The use and implementation of elements of automated technologies dated back to the first half of the 20th century and were determined by high manual labor costs [29]. The first step on this path was the use of special devices for collecting berries, which were trays, combs, they are simple in design, operation and worked on the principle of "combing" berries, these were the first elements of mechanization in the process of harvesting currants. With their help, the labor productivity of collectors increased by $15-20 \%[27,52,53]$. By the mid-1950s-1960s, more advanced combines were developed in different countries: Berry, Wacker E. S. 8, Mi-Dox, PAV-8, EYAM-200-8 (Fig 1) [14,17, 28]. The operation of these harvesters was based on shaking the shoots with vibration. At the same time, the complete replacement of manual labor was not provided: one collector had to tilt the shoots over the catcher, and the other collector had to hold the vibrator along the branches from the base to the top, grabbing each branch in turn with a fork. Due to sharp and frequent fluctuations, the berries were poured into the catcher. The branches were practically not damaged by the oscillating fork. The quality of berries harvested by combine harvesters is not inferior to berries harvested by hand. We can say that even in those years, the creation of such electric berry harvesting machines was an innovative breakthrough in berry farming.

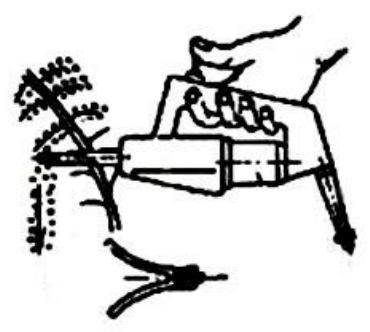

Fig. 1. Berry harvesting machine model EYAM-200-8, general view 
However, due to the low quality of the vibrators and low labor productivity, these models of harvesters were removed from mass production. The prospect of using berry harvesting equipment determined a decrease in the profitability of berry crop production: manual labor costs were reduced by 10-15 times and direct operating costs were reduced by $50-70 \%$. Thus, it was possible to increase the productivity of mechanized labor by $4-8$ times compared to manual labor. The prospect of using berry harvesting equipment determined an increase in the profitability of berry crop production: manual labor costs were reduced by 10-15 times and direct operating costs were reduced by $50-70 \%$. With the use of the first berry harvesters, the requirements for the selection and quality of cultivation sites began to increase. For black currants, there were low places, while for red and white currants were used warmer and well-lit places, with relatively light soils. However, in all cases, the plots had to have good protection from cold winds (bordering blocks of trees and shrubs) $[5,11,14,37]$.

In the 1970 s and $80 \mathrm{~s}$, designers and scientists developed new models of berry harvesters that can replace the labor of 300-350 pickers and harvest an area of 30-40 hectares per season [3, 45]. In New Zealand, the Lavin combine was designed, in England -"Smallford" and "Beldain", in the USA - "Нarvi", in России - MPYa-1 and MPYa-1A (Fig. 2).
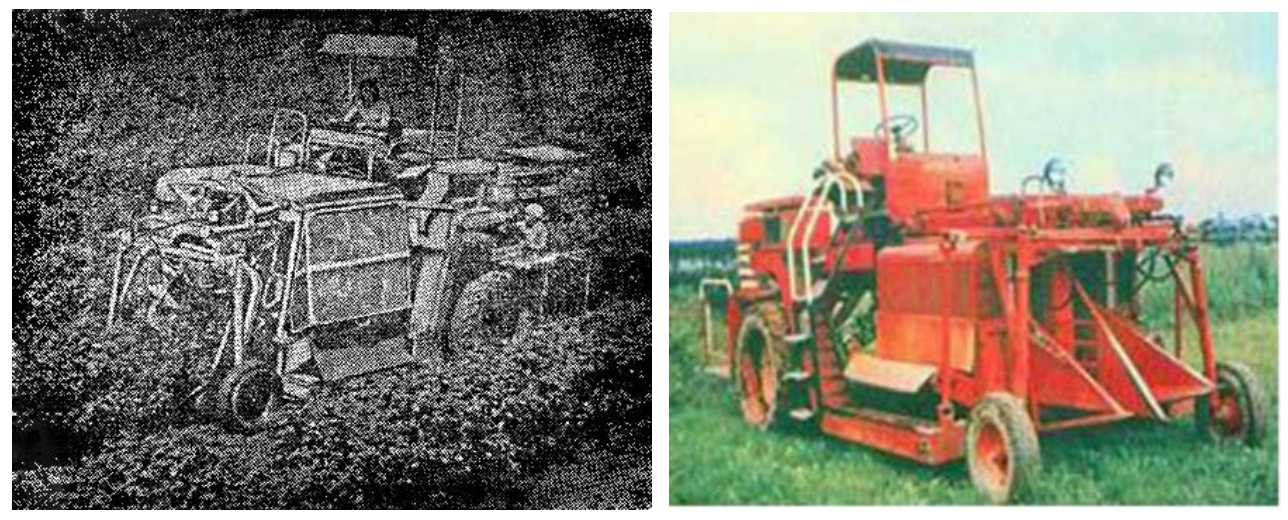

Fig. 2. Berry harvesters: MPYa-1(A) and MPYa-1A (B) (Kulikov, 2009)

The work of these models is associated with the complete "capture" of the currant bush and mechanical shaking of the shoots, the berries fell on the catcher and then - into the conveyor system and were sent for cleaning and packing. However, the developers of agricultural machinery faced a number of problems in the use of automation tools during harvesting: breakage of bushes, damage to berries, the zone of determining the location of berries on bushes, high yield losses, etc. [18, 61].

Certain advances in computer technology and pressure from the global market, put the development of the berry industry at a fundamentally new stage, there was a more advanced technology, taking into account the requirements of the manufacturer, characterized by high quality of work, simplicity in design and low-cost service.

In the 1990s-2000s, a new model of the Jonnas berry harvester was developed in Finland, modifications of which are still used by farmers, in Poland - KPS-3, KSP-4, RSP-5, AREK, JAGODA JAREK 5, in Russia - the KSM-5 modular harvester (Fig. 3) [16,22]. 


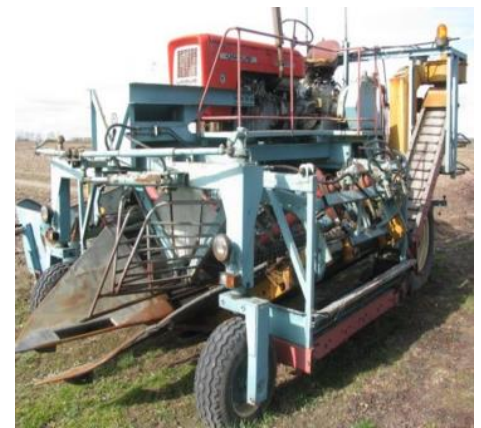

A

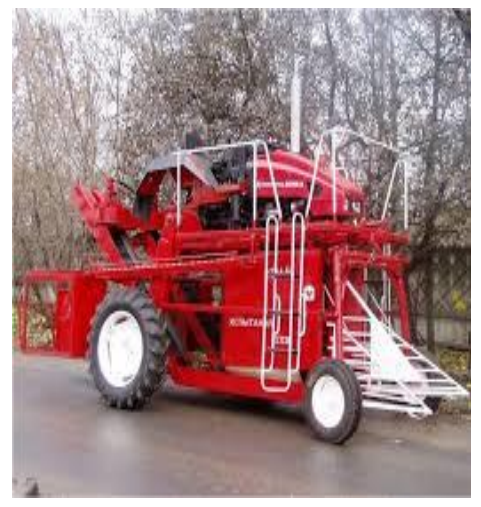

$\mathrm{C}$

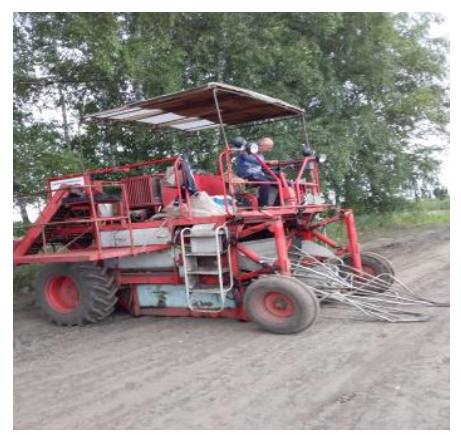

B

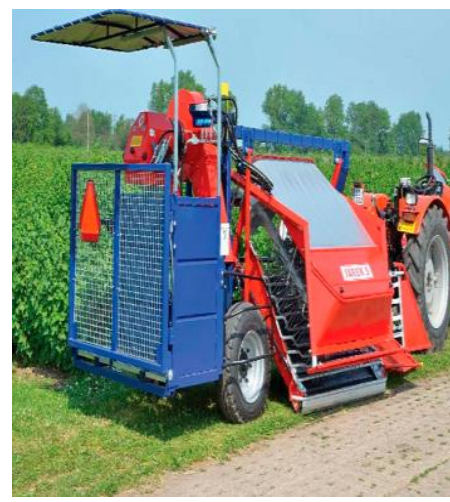

$\mathrm{D}$

Fig. 3. Berry harvesters: KPS-3 (A), «Jonnas» (B), KSM-5 (C), JAGODA JAREK 5 (D)

These harvesters can also replace the labor of 300-350 people and provide productivity up to $0.1-0.2 \mathrm{ha} /$ hour of harvesting berries from the plantation.

\subsection{The cultivar in agronomic practice of industrial cultivation of currants}

With the introduction of new berry harvesters, the profitability of production has increased. The success of using mechanization and automation tools in production depends not only on the equipment and its models, but also on the species, cultivar, and method of growing the crop $[2,60]$.

There are modern requirements for growing currants, which include: 1. planting scheme (the distance between plants in a row and row spacing); 2 . limiting features that affect the quantity and quality of the harvest (the area where berries are placed in the crown of the bush, the simultaneous maturation of berries in the cluster, the force of separation and crushing of berries); and 3. non-limiting features that affect the damage to plants during harvesting, the rate of accumulation of unproductive wood and the life of plantings (crown shape, lack of fallen branches, width of the base and height of the bush, diameter of perennial branches, duration of removable maturity) [9, 32, 37, 41, 43, 49, 58]. At the end of the 1980s, the main requirements for currant cultivars suitable for mechanized harvesting were developed: high yield, resistance to the most common fungal diseases, bush height$120-160 \mathrm{~cm}$, width - 140-150 cm, bush base - no more than $30 \mathrm{~cm}$, simultaneous ripening of berries in the cluster (more than $90 \%$ ), berry separation force within $0.5-1.5 \mathrm{~N}(50-150$ $\mathrm{g})$, berry crushing force-more than $2 \mathrm{~N}(200 \mathrm{~g})$, duration of removable maturity - more than 
7 days, permissible threshold damage to bushes - no more than $30 \%$ of dead branches over 6 years of exploitation [4, 7, 38]. For production testing, black currant cultivars 'Ben Lomond', 'Ben Connan', 'Ojebin', 'Ores' were recommended, which had a minimum percentage of damage to shoots during machine harvesting [46, 50, 63].

In a number of countries, scientists have developed new breeding programs for Ribes, where special attention is paid to the genetic characteristics of the variety: morphological characteristics, high yield, duration of removable maturity, adaptability to environmental factors, resistance to diseases and pests $[8,6,30,33,35,36,50,51]$. Breeding programs are implemented in Belgium, the Czech Republic, Denmark, Finland, France, Germany, Hungary, Latvia, New Zealand, Poland, Sweden, the Netherlands, Great Britain, Russia, Ukraine, Canada, and America [26]. Along with traditional field methods, new modern laboratory methods and techniques (molecular and biological) are being introduced, which allow to identify the resistance of cultivars to biotic factors and, first of all, to the most dangerous diseases and pests of currants: American powdery mildew (Sphaerotheca morsuvae), leaf spot (Gloeosporidiella ribis), columnar rust (Cronartium ribicola Dietr.), bud mite (Cecidophyopsis ribis).

The use of genetic methods in breeding allowed to identify and recommend for industrial cultivation a number of resistant cultivars to columnar rust ( $\mathrm{Cr}$ gene): black currant - 'Titania', 'Ben Tirran', 'Ben Sarek', 'Ceres', 'Consort', 'Coronet'; red currant 'Minnesota 71', 'Rovada', 'Rondom', 'Rotet', 'Wilder'; white currant -'White Currant 1301'; 'White Imperial' [9, 19, 20]; to the bud mite (Ce gene): black currant cultivars 'Ben Hope', and 'Ben Gairn' [26].

Agricultural producers in a number of countries use new breeding achievements of scientists. At present, both new promising and competitive currant cultivars are used for industrial planting of the plantation, as well as the old ones - stably fruiting, with high commercial and consumer qualities of berries. The most common cultivars of black currant are found in industrial plantations in Denmark - 'Risager', 'Wellington XXX', 'Roodknop', 'Wallace Seedling', 'Amos Black ', 'Ben Lomand', 'Ben Newi'; in Norway - 'Ben Lomond', 'Ojebyn', 'Ben Tirran', 'Ben Lomond', 'Ben Hope','Matkakoski', 'Narve Viking', 'Boskoop Giant', 'Roodknop', 'Brodtorp'; in the Netherlands -'Wellington XXX', 'Baldwin Hilltop', 'Silvergieters Schwarze', 'Black Reward', 'Roodknop', 'Brodtorp'; in Sweden - 'Ojebyn', 'Stella I', 'Stella II'; in Austria - 'Rosenthal', in the USA - 'Ben Tirran', 'Ben Connan', 'Ben Alder', 'Ben Sarek', 'Titania' [2, 10, 23]; In Russia - 'Talisman', 'Cardinal', 'Tamerlan', 'Kipiana', 'Gamma', 'Iskushenie', 'Azhurnaya', Orlrvskaya Serenada and 'Zusha' [55].

Red and white currants are grown on a smaller scale than black currants. The main production cultivars for the USA, Switzerland, Poland, Italy, and Norway are 'Jonkheer van Tets', 'Red Lake', 'Rondom', 'Rovada', 'Viking' (synonyms 'Hollandische Rote', 'Norwegian Red Dutch', 'Rod Hollandsk'), 'Red Poll', 'Roodneus', 'Rosetta', 'Detvan', 'Blanka', 'White Currant 1301', 'White Dutch', 'White Versailles', as well as 'Augustus', a new high-yielding cultivar.

\subsection{Planting scheme}

Currant farmers who use mechanization tools in production ensure the optimal distance between rows for the operation of equipment. A well-chosen planting scheme determines the yield, product quality, and early fruitfulness of plantings, and reduces labor costs during harvesting [9]. The density and location of berry bushes on the area significantly change the lighting conditions, heat and water-air modes of plants, and reduce the percentage of diseases and pests [13].

Placement schemes in a row should ensure the continuity of the crown and the absence of plant loss $[56,64]$. 
Inter-row spacing of 2.5-3.0 m, the distance of currant bushes in the row 0.3-0.6 m, height of bushes $1.1-1.8 \mathrm{~m}$, the width of the strip of bushes $1.1-1.5 \mathrm{~m}$, base diameter of the shrub $0.2-0.35 \mathrm{~m}$, diameter of branches at the base $0.8-2.0 \mathrm{~cm}$ and the location of the berries on the bush from the soil surface at least $25 \mathrm{~cm}$ are required for the mechanized cultivation of currants. Plantings with such a layout are recommended to be operated for 68 years, and plantings with row spacing of $2.0-2.2 \mathrm{~m}$ should be used for 5-6 years [59, www.websadovod.ru]. In the Institute for Fruit Growing, Belarus, horizontal planting of black currants is often used according to the $3.5 \times 0.5 \mathrm{~m}$ scheme, which increases the growth of fruit-bearing branches and allows for efficient operation of the berry harvester, creating a continuous strip of plants in a row, thus increasing the number of fruit-bearing branches by 1.1-1.7 times, productivity by $1.3 \mathrm{t} / \mathrm{ha}$ and increasing the profitability of crop cultivation by $35 \%[34]$.

In the University of Life Sciences in Lublin (Uniwersytet Przyrodniczy w Lublinie), for red and white currants, the most optimal distance for mechanized harvesting is considered to be $3 \times 0.5 \mathrm{~m}$. Using a distance between plants of $0.5 \mathrm{~m}$ allows to place up to 8000 bushes on one hectare. Dense planting contributes to higher yields per unit area.

This planting scheme is often used when growing currants in tunnels or on a trellis (cordon training system): plants are planted at intervals of $1.2-1.3 \times 0.3-0.75 \mathrm{~m}$, tied to permanent trellises with wire, bamboo sticks are used as a support. With this planting scheme the number of plants per 1 ha. reaches 25000 - 27000 (Fig. 4).

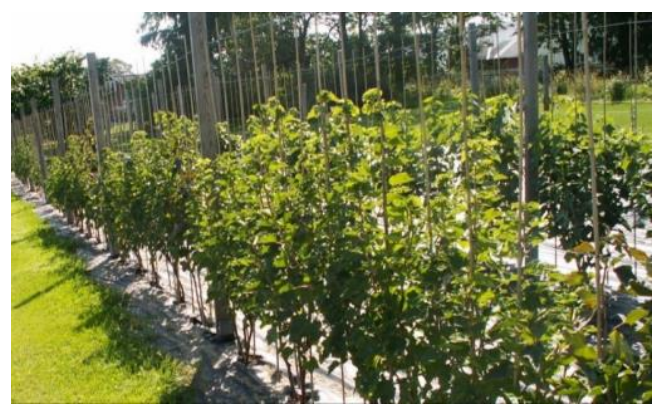

A

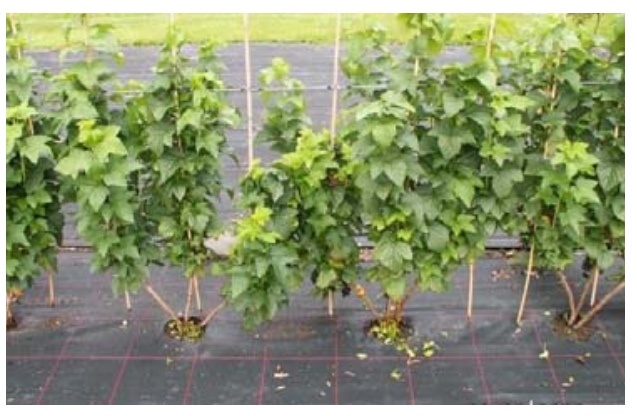

B

Fig. 4. Cultivation of red (A) and black (B) currants on a trellis (Strbac, S., 2009)

The compacted planting scheme is important and determines the yield of cultivars and in some cases the plantation yield can reach 15-20 t/ha $[15,54$, www.jagodnik.pl; https://batkivsad.com.ua/ru/1184/]). For growing on a trellis, both in Poland and in Europe, the following cultivars are recommended: 'Rovada', 'Junifer', 'Roodneus', 'Jonkheer van Tets', 'Augustus'. All these cultivars are very productive, with long clusters, and they preserve the leafiness of the shoots long enough. The most popular cultivars for growing on trellis are 'Ben Tron', 'Kristin', 'Big Ben', 'Ben Hope', 'Bona'. Due to the well-established marketing system in Europe, fresh berries of these cultivars are exported to neighboring countries in special vacuum packages.

\subsection{Pruning in dense plantations}

Pruning is of paramount importance for optimizing the crop load on shoots and improving the quality of berries [1]. Pruning helps not only to maintain the necessary shape of the bush, but also provides optimal light penetration and uniform color of berries, as well as reduces the damage of cultivars by diseases and pests cker [10]. At the same time, bush pruning is one of the most time-consuming and expensive processes in the care of berry 
bushes, especially since it must be performed in a short time in spring or autumn. For the first time, mechanical pruning operations were started in 1960 in the United States and mainly horizontal pruning of the upper parts of shoots was used [40, 47, 52]. In Europe, for growing currants on a trellis, the formation of a bush is important and is carried out only with the use of mechanization tools. Pruning in a compacted planting scheme ensures the annual appearance of a certain number of zero shoots (or root shoots) and timely replacement of old, low-yielding branches, prevents thickening of the bush and allows to get high-quality berry yields without reducing the life of the plantings. Currently, there are several types of pruning in production: forming, sanitary, anti-aging and detailed. In antiaging pruning, mechanization tools are used as much as possible. Such pruning is carried out at the $5-8$-year-old age of plants, removing all dry branches, shortening (by twothirds) the branches of the entire bush and simultaneously shortening the root shoots by half. This method of gradual rejuvenation is possible for all cultivars of currants. Mechanized anti-aging pruning in the 1990s was carried out using a large-diameter circular saw installed in a horizontal position with lateral removal from the tractor, as well as machines OKS-1, OKS-0.9, PAV-8 unit, and a currant chopper mower IS-1. It was also proposed to mow the bushes with a FLU-0.8 cutter or a "Vikhr" silo harvester, simultaneously crushing the cut branches and leaving them in place. The efficiency of mechanized care for the currant plantation was increased by $50-60 \%$. However, with the mechanized method of pruning, there were a number of disadvantages (crop loss, damage to bushes). The main causes of crop loss during the formation of plants by the machine were determined by the general vibration of forming devices in contact with some fruitbearing branches; the friction of berries on the surface of branch lifts; their impact on the crown of bushes in the presence of plants falling out of a row; getting of some bent fruitbearing branches under forming devices [57, 64]. New options were proposed to reduce plant damage and loss of part of the berries: working against the background of an uncompacted crown, which made it possible to separate the berries with minimal energy consumption, so that the plants were caused minimal damage and the overall energy consumption of the machine was reduced [21]. In the 2000s, new models and devices for pruning berry plantations were developed, they are a class higher than previously developed and multifunctional: contour pruners Binger Seilzug OBS Profi (Germany) and PFP (Spain); BERTA machines for cutting bushes, ROCH machines for pruning currant shoots, SAVA multifunctional machines (Poland), and KSM-5 interchangeable-modular combines (Russia).

\section{Conclusion}

There is a clear trend in the global berry industry to intensify the production of berries for growing on an industrial scale using mechanization tools. The use of modern means of mechanization reduces production costs and dependence on hired labor. Global market trends and demand for high-quality berry products dictate the introduction of high-tech, sustainable, high-yield, early-fruiting cultivars. The development and improvement of elements of cultivation technology is an important criterion for using modern means of mechanization and automation. The main problems of farmers when growing currants are: manual labor, marketing, introduction, resistance to major diseases and pests. A properly selected plot, planting scheme and cultivar reduce the cost of currant production. The use of modern berry harvesters minimizes the use of manual labor and increases production efficiency.

Identifying easily accessible markets and selling berries at a high price are key components of success. Currant can be sold through its own sales network, supermarkets and store chains, retail and wholesale markets. Some cultivars can be exported to 
international markets. In this case, the marketing system should be aimed at uniformity of berries (standard) in quality, size and shape, berries should be of the same cultivar, and be delivered for sale in attractive vacuum containers (panettes). Production and sale of additional currant products with added value, such as jam, jelly, juice, marmalade, etc. can increase profits.

\section{References}

1. A. Bratsch, J. Williams, Virginia cooperative Extension. Publication , 438 (2009)

2. A. Dale, D.Yarborough, E.J. Hanson, R.J. McNicol, Horticultural, 16, 255 (2010)

3. A. Dale, E.J. Hanson, D.E. Yarborough, R.J. McNicol, E.J. Stang, R. Brennan, J.R. Morris, G.B. Hergert, Horticultural Reviews, 16, 255 (1994)

4. A. Kikas, L. Arus, A. Libek, H.Kaldmäe, Acta Horticulturae, 777, 263 (2008)

5. A.G. Gurin, Recommendations for the cultivation of industrial blackcurrants intended for mechanized harvesting, 21 (2001)

6. A.Yareshchenko, Y.Tereshchenko, L. Pryimachuk, E. Todosyuk, B. Mazur, Acta Horticulturae, 946, 177 (2012)

7. D. Barney, K. Hummer, Currants, Gooseberries, and Jostaberries: A Guide for Growers, Marketers, and Researchers in North America 1st Edition. Food Products Press, New York, 266 (2005)

8. D. Barney, HortScience, 31(5), 774 (1996)

9. D.L. Barney, HortTechnology, 10(3), 557 (2000)

10. D.P.Tucker, T.A. Wheaton, R.P. Muraro, Citrus tree pruning principles and practices. Horticultural Sciences (Department, Florida 1994)

11. E. Day, The agricultural engineer, 36(2), 45 (1981)

12. E. Mitcham, Quality of berries associated with preharvest and postharvest conditions. In: BerryFruit by the ed. Zhao, Y., Value-Added Products for Health Promotion. CRC Press/Taylor \& Francis, 207 (2007)

13. E.S. Boyko, Formation of gooseberry plantations for mechanized harvesting. Dissertation, All-Russian Horticultural Institute for Breeding, Agrotechnology and Nursery, Moscow, Russia, 133 (2008)

14. E.Yu. Koveshnikova, Pomiculture and small fruits culture in Russia, 11, 411 (2004)

15. F. Pitsioudis, W. Odeurs, P. Meesters, Acta Horticulturae, 838, 33 (2009)

16. F.F. Sazonov, O.V. Danshina, Horticulture and viticulture, 2, 22 (2016)

17. Foreign Agricultural Trade of the United States: Trade by Countries for Calendar Year (Classic Reprint) (United States Department of Agriculture, Forgotten Books,70, 1958)

18. G.F. Thiele, Short term cropping of black currants for mechanical harvesting. Dissertation. Lincoln College, New Zealand (1979)

19. H.L. Pedersen, Ecofruit. 14th International Conference on Organic Fruit-Growing, 2224 February 2010, Tyskland, 212 (2010)

20. H.L. Pedersen, Fruit Varieties Journal, 52(1), 6 (1998)

21. I.G. Smirnov, Pomiculture and small fruits culture in Russia, 6, 230 (1999)

22. I.M. Kulikov, Perspective resource-saving technology for shrubby berry plantations, Moscow, FGNU "Rosinformagrotech", Russia, 52 (2009) 
23. J. Fischbach, C. Dale, Research Bulletin, 13, 1 (2010)

24. J.R. Morris, Proceeding of the ASEV 50th Anniversary Annual Meeting, Seattle, USA, 51(5), 55 (2000)

25. K.E. Hummer, A. Dale, Forest Pathotology, 40, 251 (2010)

26. K.E.Hummer, D.L. Barney, HortTechnology, 12(3), 377 (2002)

27. L. Harmat, A. Porpaczy, D. Himelrick, G. Galletta, Currant and gooseberry management. In: Small fruit crop management by the ed. Galletta, G., Himelrick, D., Prentice Hall, Englewood Cliffs, N.J, 245 (1990)

28. M. Duncan, B. Bickel, U.S. Agricultural Exports -A Boon to Farmers. Monthly Review, 28(3), 3 (1976)

29. M. Jatoi, T. Jemric, S.Sito, Glasnik Zaštite Bilja, 40(4), 94 (2017)

30. M. Luffman, HortTechnology, 10(3), 555 (2000)

31. M. O'Brien, B.F. Cargill, R.B. Fridley, Principles and Practices for Harvesting and Harling Fruits and Nuts (AVI Publishing Westport, USA,1983)

32. M. R. Vagiri, Department of Plant Breedingand Biotechnology, Swedish University of Agricultural Sciences, 58 (2012)

33. M. Stanisavljević, Ž.Tešović, Breeding black currants, and characteristics of promising hybrids (Springer, Dordrecht 1994)

34. M.N. Avdeev, Fruit growing in Belarus: traditions and modernity, International scientific conference 13-16 October 2015, Samokhvalovichi, Belarus, 310 (2015)

35. O. Panfilova, M.Tsoy, O.Kalinina, S.Knyazev, E3S Web of Conferences, 176(22), 1 (2020)

36. O. Panfilova, O. Kalinina, O. Golyaeva, S. Knyazev, M. Tsoy, Research in agricultural engineering, 66, 156 (2020)

37. O.F. Yakimenko, Horticulture and viticulture, 3, 21 (2001)

38. O.F.Yakimenko, V.S. Novopokrovsky Evaluation and selection of black currant varieties for machine harvesting. Michurinsk, 45 (1988)

39. O.V. Danshina, Selection evaluation of black currant forms for suitability for machine harvesting. Dissertation, Bryansk State Agrarian University, Russia, 165 (2017)

40. P.J. Jutras, D.W. Kretchman, Florida state Horticultural Society, 32 (1962)

41. Q. Zhand, F.J. Rierce, Agricultural Automation: Fundamentals and practices. CRC press, New York, USA (2013)

42. R. Brennan, J. Graham, Functional Plant Science and Biotechnology, 1, 22 (2009)

43. R.M. Brennan, Currants and Goosberries Ribes species Saxifragaceae. In: Encyclopedia of Fruit and Nut Crops, CABI, Cambridge MA, 1 (2006)

44. R.M. Brennan, J. Caligari, R. Clark, P.N. Brás de Oliveira, C.E. Finn, J.F. Hancock, D. Jarret, G.A. Lobos, S. Raffle, D. Simpson, Horticulture: Plants for People and Places, 1, 301 (2014)

45. S. Olander, Acta Horticulturae. 965, 171 (2012)

46. S. Pluta, Acta Horticulturae, 946, 27 (2012)

47. S. Sansavini, Acta Horticulturae, 65, 183 (1978)

48. S. Strbac, Cordon training system for black and red currant (2009)

49. S.M. Paunović, M.Nikolić, R. Miletić, Contemporary Agriculture 66(1-2), 21 (2017)

50. S.Pluta, E. Żurawicz, Acta Horticulturae, 777, 447 (2008) 
51. S.Strautina, I. Krasnova, I. Kalnina, A. Sasnauskas, V. Trajkovski, O. Tikhonova, Acta Horticulturae, 926, 53 (2012)

52. T. Burks, D. Bulanon, R. Suk-You, A. Sundararajan, Orchard and vineyard production automation. In: Agricultural Automation: Fundamentals and Practices by the ed. Zhand, Q., Pierce, F.J. CRC press, New York, USA, 150 (2013)

53. T. Burks, F. Villegas, M. Hannan, S. Flood, B. Sivaraman, V. Subramanian, J. Sikes, HortTechnology, 15(1), 79 (2005)

54. T.V. Noskova, Biological features of yield formation and its quality in currant cultivars on the trellis in the CChR. Dissertation, Michurinsk State Agrarian University, Russia, 175 (2012)

55. T.V. Zhidekhina, State and prospects of development, 104 (2006)

56. U. Neumann, P.Sorg, Gartenbau, 24(7), 213 (1977)

57. U.S. Patent and Trademark Office (2002), http://patft.uspto.gov/

58. V. Davis, Rural Manpower Center, Michigan state University, 16, 205 (1969)

59. V.G. Tolstoguzova, V.F. Vorobiev, E.S. Boyko, Horticulture and viticulture, 6, 12 (2007)

60. W.L. Sims, Cultural practices for fruit vegetables. Rural Manpower Center, Michigan State University, 1, 225(1969)

61. Y. Sarig, Journal of Agricultural Engineering Research, 54(4), 265 (1993)

62. Yu.A. Utkov, V.N. Sorokopudov, S.M. Medvedev, Vestnik of the Kursk State Agricultural Academy, 7, 139 (2018)

63. Z. Salamon, Acta Horticulturae, 352, 109 (1993)

64. Z. Salamon, S. Placek, Hasio ogrodnicze, 44(9), 8 (1987) 